\title{
Micro-computed tomographic evaluation of root canal morphology in mandibular first premolars from a Colombian population
}

\author{
Jaime O. Moreno', Martha L. Duarte', Marilia F. Marceliano-Alves², Flávio R.F. Alves²,3, José \\ F. Siqueira Jr. ${ }^{2,3}$, José C. Provenzano²
}

1. Universidad Santo Tomás, Facultad de Odontologia, Bucaramanga, Colombia

2. Universidade Iguaçu (UNIG), Faculdade de Odontologia, Departamento de Endodontia e Pesquisa Odontológica, Nova Iguaçu, Rio de Janeiro, Brasil.

3. Universidade do Grande Rio, Programa de Pós-Graduação em Odontologia, Rio de Janeiro, Brazil.

\begin{abstract}
Dental anatomy can vary significantly between different populations from different countries. Dental anatomical variations are of great interest to the dental professional, especially to endodontists, since they can influence the outcome of endodontic treatment. The purpose of the present study was to describe the anatomical variations of the root canal in mandibular first premolars in a population from Colombia, using micro-computed tomography. Fifty mandibular first premolars were scanned on a SkyScan 1174 and the microcomputed tomographic images were reconstructed. Anatomy was assessed using three-dimensional models. The parameters used were: Vertucci's classification, area and volume, perimeter, circularity, and major and minor diameter at 1,2 and $3 \mathrm{~mm}$ from the apical foramen. According to the Vertucci's classification, teeth were classified as: types I (40\%), V (24\%), VII (4\%) and III (4\%), with $28 \%$ not classifiable. C-shaped canals were found in $1.8 \%$
\end{abstract}

of the sample. Mean evaluations at 1,2, $3 \mathrm{~mm}$ of the foramen were as follows, respectively: perimeter $1.07 \pm 0.57,1.27 \pm$ 0.78 and $1.57 \pm 0.84 \mathrm{~mm}$; circularity $0.59 \pm 0.19,0.57 \pm 0.20$ and $0.56 \pm 0.22 ;$ maximum diameter $0.41 \pm 0.23,0.48 \pm 0.33$ and $0.60 \pm 0.37 \mathrm{~mm} ;$ minimum diameter $0.24 \pm 0.10,0.26 \pm$ 0.11 and $0.21 \pm 0.13 \mathrm{~mm}$. Mean total area and volume were $61.27 \pm 16.47 \mathrm{~mm}^{2}$ and $12.47 \pm 4.95 \mathrm{~mm}^{3}$, respectively. There was wide anatomical variation in mandibular first premolars from Colombian individuals, reinforcing the need for proper anatomical knowledge to establish more effective strategies for endodontic treatment.

Received: October 2020; Accepted: February 2021.

Keywords: anatomical model - X-Ray microtomography bicuspid.

\section{Avaliação microromográfica da morfologia interna de canais de primeiros pré-molares de uma população colombiana}

\begin{abstract}
RESUMO
A anatomia dentária pode variar significativamente entre diferentes populações, de diferentes países. As variações anatômicas dentais são de grande interesse para o profissional da odontologia, principalmente para os endodontistas, pois podem influenciar no resultado do tratamento endodôntico. Descrever as variações anatômicas do canal radicular dos primeiros prémolares inferiores em uma população da Colômbia, usando a micro tomografia computadorizada. Cinquenta primeiros prémolares inferiores foram digitalizados em um SkyScan 1174 e as imagens tomográficas foram reconstruidas e a anatomia foi avaliada por meio de modelos tridimensionais. Os parâmetros utilizados foram: classificação de Vertucci, área e volume, perímetro, circularidade e diâmetros maior e menor a 1, 2 e $3 \mathrm{~mm}$ do forame apical. De acordo com a classificação de Vertucci, os dentes foram classificados em: tipos I (40\%), V (24\%), VII (4\%) e III (4\%), sendo $28 \%$ não classificáveis.
\end{abstract}

Canais em forma de C foram encontrados em 1,8\% da amostra. As avaliações médias em 1, 2, $3 \mathrm{~mm}$ do forame foram as seguintes, respectivamente: perímetro $1,07 \pm 0,57,1,27 \pm 0,78$ e 1,57 $\pm 0,84 \mathrm{~mm}$; circularidade 0,59 $\pm 0,19,0,57 \pm 0,20$ e 0,56 $\pm 0,22$; diametro maior $0,41 \pm 0,23,0,48 \pm 0,33$ e 0,60 $\pm 0,37$ $\mathrm{mm}$; diâmetro menor 0,24 $\pm 0,10,0,26 \pm 0,11$ e 0,21 $\pm 0,13$ $\mathrm{mm}$. A média da área total e do volume foram $61,27 \pm 16,47$ mm2 e 12,47 44,95 mm3, respectivamente. Houve uma grande variação anatômica nos primeiros pré-molares inferiores de colombianos, reforçando a necessidade de conhecimento anatômico adequado para estabelecer estratégias mais eficazes para o tratamento endodôntico.

Palavras-chave: modelo anatômico - microtomografia de raios- $X$ - bicúspide. 


\section{INTRODUCTION}

The main objective of endodontic treatment is to prevent or treat apical periodontitis ${ }^{1}$. The persistence or emergence of an apical periodontitis lesion after treatment can be regarded as a failed outcome and may be associated with difficulties encountered during endodontic intervention ${ }^{2}$.

Chemomechanical preparation can be considered as the main phase of root canal treatment ${ }^{3}$. It consists of cleaning, shaping, and disinfecting the main canal, through the mechanical action of instruments and the chemical effects of irrigant solutions, creating appropriate intracanal conditions to receive the filling material ${ }^{4-6}$.

Anatomical complexities of the root canal system can pose a major challenge during endodontic treatment, so knowledge of internal anatomy and its variations is of utmost importance for success ${ }^{7,8}$. Endodontic instruments and irrigants have limitations in reaching and disorganizing bacterial biofilms located in areas such as isthmuses, ramifications and recesses, which often require special strategies for cleaning and disinfection ${ }^{1}$.

Difficult-to-reach irregular areas can harbor remnants of pulp tissue or residual infected debris, which may compromise the treatment outcome ${ }^{9}$. Mandibular premolars can present complex anatomy; according to the Vertucci's classification, ${ }^{7}$, these teeth can present several anatomical classifications, from type I to $\mathrm{V}$. In addition to these variations, these teeth can also present a C-shaped canal, which is a ribbonshaped orifice, formed when the canals merge to form a $180^{\circ}$ arc and a narrow strip of curved pulp tissue is formed ${ }^{10}$. A C-shaped canals presents a serious challenge for adequate endodontic treatment. Root canal anatomy may vary according to ethnic factors ${ }^{11}$, sex ${ }^{12}$ and age $^{13}$. Most previous studies were performed in Caucasian populations ${ }^{14}$. Similar investigations in other populations in South America are less frequent, especially in Colombia, where studies on internal dental anatomy are rare. Thus, the purpose of the present study was to describe the root canal morphology of the mandibular first premolar in a Colombian population using microcomputed tomography (micro-CT) as the evaluation method.

\section{MATERIALS AND METHODS}

Fifty mature mandibular first premolars with intact crowns, available from the Bank of Human
Permanent Teeth of the Santo Tomás University, Bucaramanga, Colombia, were used in this study. Teeth had been extracted for orthodontic reasons unrelated to this study. Consent was secured prior to tooth donation. The teeth evaluated in this study were from patients from the metropolitan region of Bucaramanga, Colombia, including the cities Floridablanca, Girón, Lebrija, and Piedecuesta. The population in this region is miscegenated, as in other Latin American countries. This study was conducted under the principles established in Resolution 08430 of Colombia and approved by the Ethics Committee of Santo Tomás University. Exclusion criteria included teeth with incomplete root formation, root resorption, crown and/or root fractures, previous endodontic treatment and extensive restorations and/or caries.

The teeth were scanned on the SkyScan 1174v2 micro-CT device (Bruker-microCT, Kontich, Belgium) with a $50 \mathrm{kV}$ source at $800 \mu \mathrm{A}$, with the following parameters: rotation step of $1.0^{\circ}$, a $360^{\circ}$ rotation around the vertical axis, and $17 \mu \mathrm{m}$ pixel size. The image of each specimen was reconstructed from the apex to the cementoenamel junction with the NRecon v.1.6.9 software (Bruker-microCT), which provided transversal axial sections of the internal structure. After this procedure, three-dimensional models of the dentin and canals were obtained through an automatic segmentation threshold with the CTAn V.1.13 software (Bruker-microCT). Subsequently, the software CTVol v.2.2.1 (BrukermicroCT) was used for visualization and qualitative evaluation of root canal morphology according to the Vertucci classification.

Images of each tooth were evaluated by two observers, and by a third in case of disagreement. The evaluation parameters included: Vertucci's classification, two-dimensional data of root canal perimeter, circularity, and major and minor diameters at 1,2 and $3 \mathrm{~mm}$ short of the apical foramen, as well as three-dimensional data of the total area and volume of the root canals.

\section{RESULTS}

According to the Vertucci classification, $40 \%$ of the mandibular first premolars were categorized as type I, while $32 \%$ were distributed among types III, V and VII (Fig. 1, Table 1). The remaining $28 \%$ of the tooth specimens did not meet any of the Vertucci classification types and were considered 


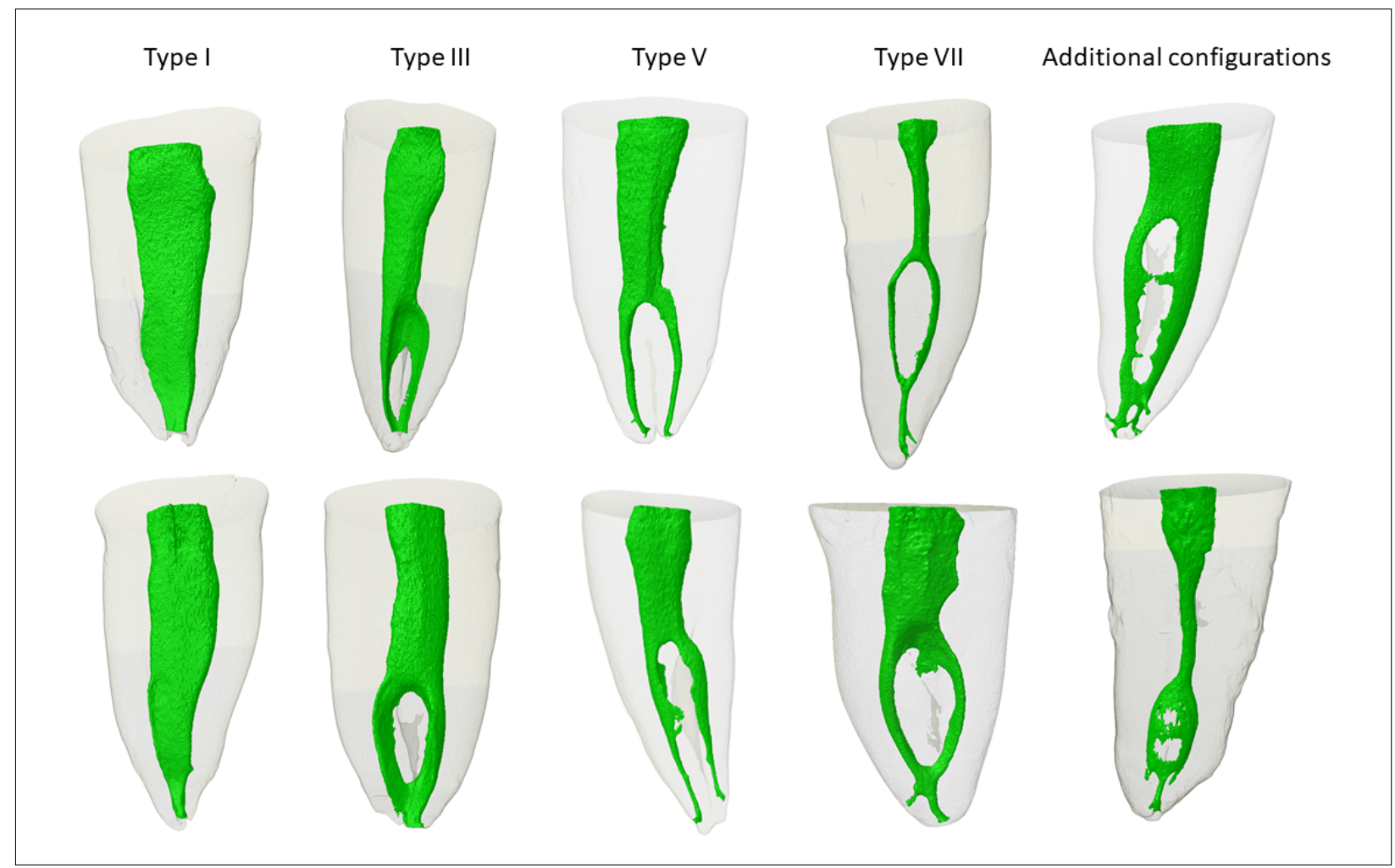

Fig. 1: Types of canals found in Colombian first mandibular premolars according to the Vertucci classification (1984).

as additional configurations. Of these, the most frequent configuration was type 1-2-3 (six teeth), followed by configuration 1-3 (three teeth) (Table 2). C-shaped canals were found in $1.8 \%$ of the specimens (Fig. 2). Table 3 shows the data from the two and three-dimensional evaluations.

\section{DISCUSSION}

Knowledge of the internal and external anatomy of the different tooth groups is essential for an endodontic treatment with favorable prognosis. Some studies have associated the complexity of

\begin{tabular}{|c|c|c|}
\hline $\begin{array}{c}\text { Vertucci } \\
\text { classification }\end{array}$ & Specimens (n) & Frequency (\%) \\
\hline Type I & 20 & 40 \\
\hline Type III & 2 & 4 \\
\hline Type V & 12 & 24 \\
\hline Type VII & 2 & 4 \\
\hline $\begin{array}{l}\text { Additional } \\
\text { configurations }\end{array}$ & 14 & 28 \\
\hline Total & 50 & 100 \\
\hline
\end{tabular}

the root canal system with the failure of endodontic treatment, usually because of the difficulties in attaining proper disinfection throughout the system irregularities ${ }^{15,16}$. Thus, the aim of this study was to contribute to the knowledge of the anatomy of mandibular premolars, a tooth with recognized complexity in internal anatomy, from a Colombian population that had not been the subject of an anatomical study by micro-CT.

Micro-CT is an excellent non-invasive, nondestructive tool for assessing internal and external

\begin{tabular}{|c|c|}
\hline $\begin{array}{l}\text { Additional } \\
\text { configuration }\end{array}$ & Specimens (n) \\
\hline $1-3$ & 3 \\
\hline $1-4$ & 1 \\
\hline $1-2-3$ & 6 \\
\hline $1-3-2$ & 1 \\
\hline $1-2-1-2$ & 1 \\
\hline $1-2-1-2-1-3$ & 1 \\
\hline $1-2-4-3-4-3$ & 1 \\
\hline
\end{tabular}




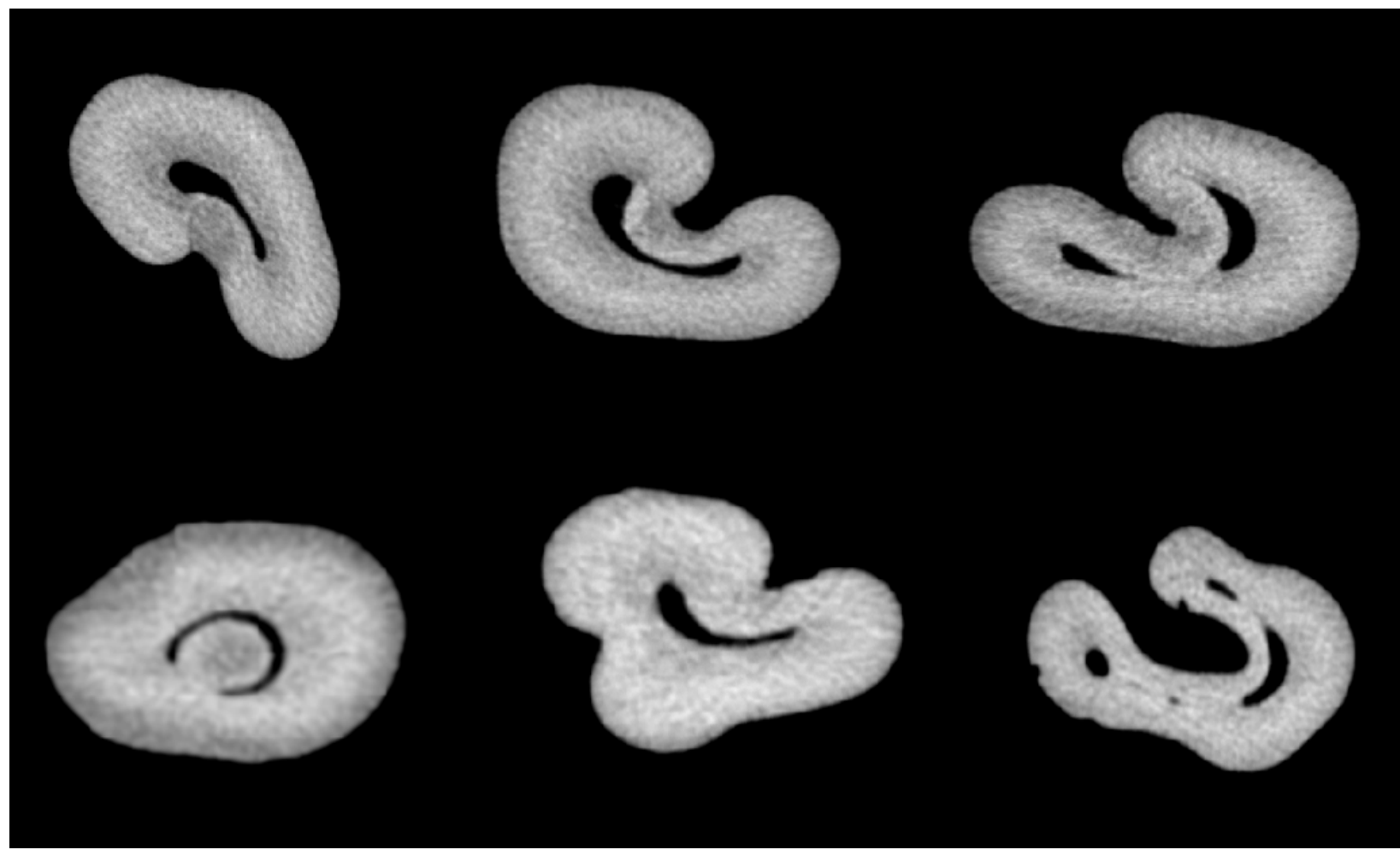

Fig. 2: Cross-sectional representative images of $C$-shaped canal found in the sample of Colombian individuals.

dental anatomy through the reconstruction of threedimensional models. In the present study, a pixel size of $17 \mu \mathrm{m}$ resolution was used, which is efficient to demonstrate the complexity of root canal anatomy ${ }^{17}$. In this study, the Vertucci type I configuration was the most prevalent ( $40 \%$ of cases), in contrast to a systematic review that found a frequency of this configuration almost twice as high in other countries $^{14}$.

The prevalence of Vertucci class V canals in the present study of a Colombian population (24\%) is similar to prevalence reported in other studies that used micro-CT, including specimens evaluated from populations of China and Saudi Arabia with a frequency of approximately $21 \%{ }^{18,19}$. It should be noted that some studies ${ }^{18,19}$ did not evaluate data such as apical canal diameter (Table 3 ), which could be valuable to plan the instrument size and other preparation strategies ${ }^{20}$.

Vertucci types III and VII configurations had the lowest frequencies in this study, each occurring in $2 \%$ of the sample. Similar findings were reported by Liu et al. ${ }^{21}$, who found $2.6 \%$ for type III and $0.9 \%$ for type VII. Together, types III, V and VII and the additional configurations comprised $60 \%$ for the evaluated premolars, highlighting the complex,
Table 3. Data from the total area and volume and other parameters evaluated at 1, 2 and 3 $\mathrm{mm}$ from the apical foramen (mean \pm standard deviation) of Colombian mandibular first premolars as evaluated by micro-computed tomography

\begin{tabular}{|c|c|c|}
\hline Parameter & Mean \pm SD & Range \\
\hline Area $\mathbf{~ m m 2}$ & $61.27 \pm 16.47$ & $27.53-96.51$ \\
\hline $\begin{array}{c}\text { Volume } \mathbf{~ m m} 3 \\
\text { Perimeter }\end{array}$ & $12.47 \pm 4.95$ & $2.91-22.95$ \\
\hline $\mathbf{1} \mathbf{~ m m}$ & $1.07 \pm 0.57$ & $0.05-2.79$ \\
\hline $\mathbf{2} \mathbf{~ m m}$ & $1.27 \pm 0.78$ & $0.20-4.08$ \\
\hline $\mathbf{3} \mathbf{~ m m}$ & $1.57 \pm 0.84$ & $0.15-4.83$ \\
\hline Circularity & & \\
\hline $\mathbf{1} \mathbf{~ m m}$ & $0.59 \pm 0.19$ & $0.12-1.00$ \\
\hline $\mathbf{2} \mathbf{~ m m}$ & $0.57 \pm 0.20$ & $0.15-0.93$ \\
\hline $\mathbf{3} \mathbf{~ m m}$ & $0.56 \pm 0.22$ & $0.12-0.88$ \\
\hline Major diameter & & \\
\hline $\mathbf{1 ~} \mathbf{~ m m}$ & $0.41 \pm 0.23$ & $0.02-1.14$ \\
\hline $\mathbf{2} \mathbf{~ m m}$ & $0.48 \pm 0.33$ & $0.07-1.65$ \\
\hline $\mathbf{3} \mathbf{~ m m}$ & $0.60 \pm 0.37$ & $0.06-2.13$ \\
\hline Minor diameter & & \\
\hline $\mathbf{1} \mathbf{~ m m}$ & $0.24 \pm 0.10$ & $0.02-0.58$ \\
\hline $\mathbf{2} \mathbf{~ m m}$ & $0.26 \pm 0.11$ & $0.05-0.63$ \\
\hline $\mathbf{3} \mathbf{~ m m}$ & $0.21 \pm 0.13$ & $0.02-0.63$ \\
\hline
\end{tabular}


variable anatomy in this group of teeth. These characteristic configurations in the study population may pose greater difficulties for the clinician during endodontic management ${ }^{18,22}$.

The results of this study for canal types III, V and VII are similar to those of another study of internal anatomy using a different methodology, also carried out in Colombia ${ }^{23}$. However, Vertucci type I was less frequent in the present study. Just over $1 / 4$ of the analyzed samples were considered as an additional configuration that did not fit the Vertucci classification, similar to that reported by Alkaabi et al. ${ }^{19}$ in an Arab population.

More than half of the evaluated teeth were not Vertucci class I, i.e., they had more than one canal and/or foraminal exit. This condition can be explained by the diversity of the Colombian population and the presence of external radicular grooves, as mentioned in a previous study ${ }^{9}$. These teeth have at least 2 apical foramina, which can be a challenge for proper cleaning and disinfection, increasing the risk for a poor outcome, as the complexity of the root canal system has been associated with the failure of endodontic treatment $t^{4,15}$. The Vertucci classification can be a limitation of this study, as it can be considered to be incomplete for studies of internal tooth anatomy. This is because when the classification was created, there was no availability of a method as accurate as microCT. The presence of accessory canals does not allow objective classification, and many additional configurations or biases of interpretation may arise in the assessment.

Only one study ${ }^{22}$ with the same group of teeth and methodology in Latin America has been carried out to date, so it is not possible to make a broader comparison with other population groups. Further research with micro-CT, analyzing lower premolars in different regions of Latin America, is necessary for better morphometric comparison of this group of teeth.

\section{CONCLUSION}

The internal anatomy of mandibular premolars from the studied Colombian population proved to be more complex when compared with some other populations, with most of the teeth not being classified as Vertucci class I. Knowledge of an anatomical pattern can assist the clinician in planning the endodontic treatment and improve the prognosis. More comprehensive studies including more samples should be conducted on this and other populations to gather more data on internal anatomy.

\section{ACKNOWLEDGMENTS}

This study was conducted following an institutional agreement between the Santo Tomás de Bucaramanga University (Colombia) and the Estácio de Sá University.

\section{DECLARATION OF CONFLICTING INTERESTS}

The authors declared no potential conflicts of interest with respect to the research, authorship, and/or publication of this article.

\section{REFERENCES}

1. Siqueira JF Jr, Rôças IN. Clinical implications and microbiology of bacterial persistence after treatment procedures. J Endod 2008; 34:1291-1301.

2. Siqueira JF Jr, Rôças IN, Veiga LM, Lopes HP, Machado de Oliveira JC, Alves FR. Outlining the causes of persistent post-treatment pain in endodontics. ENDO 2009;3:185-204.

3. Byström A, Sundqvist G. Bacteriologic evaluation of the efficacy of mechanical root canal instrumentation in endodontic therapy. Scand J Dent Res 1981;89:321-328.

\section{FUNDING:}

This work was supported by grants from Fundação Carlos Chagas Filho de Amparo à Pesquisa do Estado do Rio de Janeiro (FAPERJ) (E-26/202.729/2019) and Conselho Nacional de Desenvolvimento Científico e Tecnológico (CNPq), Brazilian Governmental Institutions.

\section{CORRESPONDENCE}

Dr. Marília Fagury Videira Marceliano-Alves

Av. Abílio Augusto Távora, 2134 - Dom Rodrigo, Nova Iguaçu - RJ, 26260-045

Brasil

mmarceliano@hotmail.com

4. Schilder H. Cleaning and shaping the root canal. Dent Clin North Am 1974; 18:269-296.

5. Siqueira JF Jr, Alves FR, Versiani MA, Rôças IN, Almeida BM, Neves MA, Sousa-Neto MD. Correlative bacteriologic and micro-computed tomographic analysis of mandibular molar mesial canals prepared by self-adjusting file, reciproc, and twisted file systems. J Endod 2013;39:1044-1050.

6. Siqueira JF Jr, Pérez AR, Marceliano-Alves MF, Provenzano JC, Silva SG, Pires FR, Vieira GCS, Rôças IN, Alves FRF 
(2018). What happens to unprepared root canal walls: a correlative analysis using micro-computed tomography and histology/scanning electron microscopy. Int Endod J 2018;51:501-508.

7. Vertucci FJ. Root canal anatomy of the human permanent teeth. Oral Surg Oral Med Oral Pathol 1984; 58:589-599.

8. Vertucci FJ. Root canal morphology and its relationship to endodontic procedures. Endod Top 2005; 10:3-29.

9. Guerreiro D, Shin JM, Pereira M, McDonald NJ. Radicular groove accessory canal morphology in mandibular first premolars: micro-computed tomographic study. J Endod 2019;45:554-559.

10. Jafarzadeh $\mathrm{H}, \mathrm{Wu} \mathrm{Y}-\mathrm{N}$. The c-shaped root canal configuration: a review. J Endod 2007; 33:517-523.

11. Trope M, Elfenbein L, Tronstad L. Mandibular premolars with more than one root canal in different race groups. J Endod 1986;12:343-345.

12. Sert S, Bayirli G. Evaluation of the root canal configurations of the mandibular and maxillary permanent teeth by gender in the turkish population. J Endod 2004;30:391-398.

13. Peiris HRD, Pitakotuwage TN, Takahashi M, Sasaki K, Kanazawa E. Root canal morphology of mandibular permanent molars at different ages. Int Endod J.2008; 41:828-835.

14. Kottoor J, Albuquerque D, Velmurugan N, Kuruvilla J. Root anatomy and root canal configuration of human permanent mandibular premolars: a systematic review. Anat Res Int 2013; 2013:1-14.

15. Siqueira JF, Antunes HS, Rôças IN, Rachid CTCC, Alves FRF. Microbiome in the apical root canal system of teeth with post-treatment apical periodontitis. PLoS One 2016; 11:e0162887.

16. Moreno JO, Alves FRF, Gonçalves LS, Martinez AM,
Rôças IN, Siqueira JF. Periradicular status and quality of root canal fillings and coronal restorations in an urban colombian population. J Endod 2013;39:600-604.

17. Boschetti E, Silva-Sousa YTC, Mazzi-Chaves JF, Leoni GB, Versiani MA, Pécora JD, Saquy PC, Souza-Neto MD. Micro-CT evaluation of root and canal morphology of mandibular first premolars with radicular grooves. Braz Dent J 2017; 28:597-603.

18. Dou L, Li D, Xu T, Tang Y, Yang D. Root anatomy and canal morphology of mandibular first premolars in a Chinese population. Sci Rep 2017;7:750.

19. Alkaabi W, AlShwaimi E, Farooq I, Goodis HE, Chogle SMA. A micro-computed tomography study of the root canal morphology of mandibular first premolars in an emirati population. Med Princ Pract 2017;26:118-124.

20. Almeida BM, Provenzano JC, Marceliano-Alves MF, Rôças IN, Siqueira JF Jr. Matching the dimensions of currently available instruments with the apical diameters of mandibular molar mesial root canals obtained by microcomputed tomography. J Endod 2019; 45:756-760.

21. Liu N, Li X, Liu N, et al. A micro-computed tomography study of the root canal morphology of the mandibular first premolar in a population from southwestern China. Clin Oral Invest 2013;17:999-1007.

22. Ordinola-Zapata R, Bramante CM, Villas-Boas MH, Cavenago BC, Duarte MH, Versiani MA. Morphologic micro-computed tomography analysis of mandibular premolars with three root canals. J Endod 2013;39:1130-1135.

23. Alfonso-Rodríguez CA, Acosta-Monzón EV, López-Marín DA, Lancheros-Bonilla S, Moreno-Abello GC, Tovar ME. Description of the root canal system of mandibular first premolars in a colombian population. Oral Sci Int 2014;11:35-36. 